\title{
The analysis of CDMS by Indonesian Millennials
}

\author{
M H Saragih and R Yohanes \\ Management Department, BINUS Business School Undergraduated Program, Bina Nusantara \\ University, Jakarta, Indonesia \\ melva.saragih@binus.ac.id
}

\begin{abstract}
A consumer decision making style (CDMS) can be defined as a mental orientation that characterizes a consumer's approach to making choices. CDMS can be identified by measuring the orientation of youth consumers in general in terms of shopping and buying. There are two factors of CDMS; that is frequency to buy and amount money to buy. This research aims to analyse CDMS among Millenium generation in Indonesia. Consumer Styles Inventory (CSI) that has been widely used to examine consumer behaviour pattern in many countries is used in this research. The result shows that loyal factor fully impacts for CDMS. This study also finds that the fashion, loyal and brand are the factors which influence the consumer millennial to spend their money to buy the apparel.
\end{abstract}

Keywords: Consumer decision, Milleniu, Youth Consumer

\section{INTRODUCTION}

The development of information technology undeniably led to the occurrence cultural shift. In the 1990s Indonesian shopping culture was dominated by shopping or purchasing goods in stores and malls, but now a significant shift took place. People are starting to abandon shopping habits in shops and shopping centers and turn to online shops in modern ways. Shopping culture in the mall has not completely disappeared, but slowly and surely the culture began to erode with the disbandment of major retailers who had dominated the shopping centers in various malls in the country The e-commerce market in Indonesia is quite promising. Internet user reaching 82 million people or about $30 \%$ of the total population. Data from research institutes ICD predicts e-commerce market in Indonesia will grow $42 \%$ from year 2012-2015. The figure is much higher than Malaysia (14\%), Thailand (22\%), and Philippines (28\%).

In the middle of the growing e-commerce business in the country, research on e-commerce world is also increasing in academic and business circles. Although there are many studies on e-commerce, there are only a few studies on online consumer behavior, especially consumer decision-making style of online apparel consumption in Indonesia. The clothing sector has different qualities that cause retailers to be involved in the development of their own brands, marketing targets and polarities in the marketplace [1]. Therefore, online consumer behavior in apparel sector should be examined separately from other online products. Some research on Y generation is lately interesting to do. In various academic studies, research on millennial consumer behavior is often associated with online digital and social media [2]-[4]. In Indonesia, the study of consumer behavior of this $\mathrm{Y}$ generation need to get a large portion, because the Indonesian population in the next few years (2020-2030) will experience demographic bonus, where the productive age population will be greater (15-64 years) $70 \%$ than non-productive 
population (14 years and 64 years above) is 30\%. Among Indonesia's productive age range, the largest consumer of online products according to Mars is in the 22-29 years age range. That's why this study will survey consumers in that age. Given that the e-commerce market is still very promising in Indonesia, this research tries to reveal a millennial generation decision-making style in purchasing decisions.

\section{RELATED WORK}

A CDMS or consumer decision-making style can be defined as a mental orientation that characterizes a consumer's approach to making choices. It is a fundamental consumer personality similar to the concept of personality in psychology [5].They believe that CDMS can be identified by measuring the orientation of youth consumers in general in terms of shopping and buying. The role of young people especially in consumer decision making should be defined and examined for several reasons. Young consumers are recognized as a special market segment for a wide variety of goods and services [6].

Sproles and Kendall used data of young consumer samples in the United States to measure the basic characteristics of CDMS. They develop and validate Consumer Styles Inventory (CSI) for this purpose. CSI has been widely used to examine consumer behavior patterns in America and other countries in different product categories. The concept and content validity of the 8 characteristics of consumers was initially verified using the principle component method of varimax rotation. The factor solution describes $46 \%$ of the variations: all eigenvalue exceed 1.0 and 8 factors have confirmed. Reliability 0.74 has been observed for scale [5]. Using CSI concept, Siu et al. establishes four relatively stable consumer decision-making styles in China: Perfectionists, Brand conscious; novelty fashion conscious and hedonic recreational that shopping is recreational [7]. When the CSI concept is applied to German buyers, Mitchell and Walsh confirm the construct validity of the eight CSI factors for female buyers and four factors for male buyers. They then concluded that men were slightly less likely to be perfectionists, somewhat less aware of new modes, and less likely to be confused when making purchases than their female counterparts [8].

The most recent research on CDMS was conducted by Nair et al. connecting value and quality consciousness in India. The results are interesting, because values such as being well respected in the society and the sense of accomplishment have a significant effect on the quality consciousness [9]. Another recent study on CDMS conducted in several junior high schools in Bhutan revealed that brand conscious, quality consciousness, trendy factor and brand loyalty Factor have the most influence on the buying behavior of this generation [10].

Based on the results of studies that apply the CSI concept in various countries, this study will also apply and test the validity of the CSI, so that the results will be expected to know the pattern of consumer behavior (CDMS) like what is formed in Indonesian society.

\section{METHOD}

This study tries to see the relation eight factors in CSI. The factors consists quality awareness, brand awareness, fashion consciousness, hedonistic spending, value consciousness, impulsivity, confusion and brand loyalty. These factors are expected to influence to the two features on online shopping. The first feature relates the frequency to do online shopping and the rest relates with how much money will be spent in online shopping. Therefore, in this study two frameworks are proposed. The first framework is to see the relation eight factors in CSI to frequencly online shopping. Eight factors are independent factors and frequencly online 
shopping as a dependent factors. Likewise, the second framework is to see the relation eight factors in CSI to amount money in spent online shopping. Therefore eight factors are independent factors and amount money as a dependent factors.

To accomadate these hypothesis, the questionnaire or survey as a primary data is given through online and paper method. The questionnaire method is a technique of gathering data using the questionnaire instrument. The questionnaire was distributed to Binus students as respondents either directly through papers or link Google docs surveys, in several ways, such as forums, individual, and class. There are 93 qualified respondents to complete the questionnaire. The questionnaire used in collecting consists of 2 parts. The first part is to see the impact the relation eight factors in CSI to frequently online shopping, and the second part is to see the impact the relation eight factors in CSI to the amount money in online shopping [5]. Each parts is represented eight measures which is revealed on eighth questions as seen Table 1. Point (A) and point (B) in Table 1 column measure represent frequently and amount money, respectively in online shopping. Table 2 shows the quesitionnare for dependent variable. Each factors are represented two questions. The value of dependent variable is then summarized from two each questions.

Table 1. Factors and measure for independent variables.

\begin{tabular}{|c|c|c|}
\hline $\begin{array}{c}\mathrm{NN} \\
\mathrm{o}\end{array}$ & Factors & Measures \\
\hline 1 & $\begin{array}{l}\text { Perfectionism/high-quality } \\
\text { consciousness (buys very best } \\
\text { quality) }\end{array}$ & $\begin{array}{l}\text { Getting very good quality is very important to me. (A) } \\
\text { When it comes to purchasing products, I try to get the very best } \\
\text { (B) }\end{array}$ \\
\hline 2 & $\begin{array}{l}\text { Brand consciousness (buys more } \\
\text { expensive, well-known national } \\
\text { brands) }\end{array}$ & $\begin{array}{l}\text { The well-known national brands are best for me (A) } \\
\text { The more expensive brands are usually my choice. (B) }\end{array}$ \\
\hline 3 & $\begin{array}{l}\text { Fashion consciousness } \text { (gain } \\
\text { excitement and pleasure from } \\
\text { seeking } \\
\text { out new things). }\end{array}$ & $\begin{array}{l}\text { I usually have one or more outfits of the very latest style. (A) } \\
\text { I keep my wardrobe up-to-date with the changing apparels. (B) }\end{array}$ \\
\hline 4 & $\begin{array}{l}\text { Hedonistic/recreational } \\
\text { consciousness (find shopping } \\
\text { pleasant; shop for the fun of it) }\end{array}$ & $\begin{array}{l}\text { Shopping is a pleasant activity to me. (A) } \\
\text { Shopping is one of the enjoyable activities of my life. (B) }\end{array}$ \\
\hline 5 & $\begin{array}{l}\text { Value consciousness (looking for } \\
\text { sale prices and lower prices) }\end{array}$ & $\begin{array}{l}\text { I buy as much as possible at 'sale prices'. (A) } \\
\text { The lower priced brands are usually my choice. (B) }\end{array}$ \\
\hline 6 & $\begin{array}{l}\text { Impulsiveness (unplanned } \\
\text { shopping; unconcerned with the } \\
\text { amount they spend) }\end{array}$ & $\begin{array}{l}\text { Should plan my shopping more carefully than I do. (A) } \\
\text { I am impulsive when shopping. (B) }\end{array}$ \\
\hline 7 & $\begin{array}{l}\text { Confusion from overchoice (have } \\
\text { difficulty making choices) }\end{array}$ & $\begin{array}{l}\text { There are so many brands to choose from that often I feel } \\
\text { confused. (A) } \\
\text { Sometimes it's hard to choose which stores to shop. (B) }\end{array}$ \\
\hline 8 & $\begin{array}{l}\text { Habitual/brand-loyal orientation } \\
\text { (have favorite brands and } \\
\text { storeschoices) }\end{array}$ & $\begin{array}{l}\text { I have favorite brands I buy over \& over. (A) } \\
\text { Once I find a product or brand I like, I stick with it. (B) }\end{array}$ \\
\hline
\end{tabular}

Table 2. Factors and measure for independent variables. 


\begin{tabular}{ccl}
\hline Factors & & \multicolumn{1}{c}{ Measures } \\
\hline Frequency & 1. & Frequent in a month online shopping \\
& 2. & Average duration in a week online shopping \\
Money & 1. & The amount money spent in last month \\
& 2. & The average amount money spent in each month \\
\hline
\end{tabular}

Response was measured using Likert Scale 1 to 7 , from strongly disagree to strongly agree. Internal consistency of the eight subscales was assessed using Cronbach 's coefficient alpha. A general overview of the respondents can be categorized based on the characteristic according to gender, age, year of class, frequency of purchasing.

\section{RESULT AND DISCUSSION}

From the survey results revealed that of the 93 participants, $80.6 \%$ have ever bought clothes online. This amount is reasonable for millennial Indonesia, when compared with a study conducted by Cowart against students in the USA in 2007 who found that $61 \%$ buy clothes online [11]. Nevertheless, the survey results also show that although millennial Indonesia is not all have bought clothes online, they still look at online clothing as a reference when they want to buy clothes, some $71 \%$ of students stated that. From 93 participants only 75 participants of those who looked had purchased clothing this way. The 75 participants who indicated a history of online clothing consumption were asked to provide additional data on their online buying behavior. The scores on the eight CSI scales and two dependent variables were correlated for this group.

The first feature internet shopping is the frequency. The relation CSI dimensions with this feature can be tested on the first framework. With regression, the results can be represented as follows. The cronbach's alpha in this study is 0.78 . It means that the CSI dimensions is the real factors in identifying decision making styles of Indonesian students. It also means that these CSI elements has satisfactory level to use across international population including Indonesian millennials.

Table 3. The regression for frequent in online shopping.

\begin{tabular}{|c|c|c|c|c|c|c|c|}
\hline \multirow[t]{2}{*}{ Model } & \multicolumn{2}{|c|}{$\begin{array}{c}\text { Unstandardized } \\
\text { Coefficients }\end{array}$} & \multirow{2}{*}{$\begin{array}{c}\begin{array}{c}\text { Standardized } \\
\text { Coefficients }\end{array} \\
\text { Beta }\end{array}$} & \multirow[t]{2}{*}{$\mathrm{t}$} & \multirow[t]{2}{*}{ Sig. } & \multicolumn{2}{|c|}{$\begin{array}{l}95.0 \% \text { Confidence Interval } \\
\text { for B }\end{array}$} \\
\hline & B & $\begin{array}{l}\text { Std. } \\
\text { Error }\end{array}$ & & & & $\begin{array}{l}\text { Lower } \\
\text { Bound } \\
\end{array}$ & Upper Bound \\
\hline (Constant) & 1.206 & .787 & & 1.532 & .130 & -.366 & 2.777 \\
\hline perfect 1 & .093 & .119 & .101 & .782 & .437 & -.144 & .330 \\
\hline brand1 & -.069 & .098 & -.088 & -.699 & .487 & -.265 & .128 \\
\hline fashion1 & .125 & .098 & .173 & 1.277 & .206 & -.071 & .321 \\
\hline hedonis1 & .063 & .082 & .100 & .769 & .445 & -.101 & .228 \\
\hline value1 & -.142 & .099 & -.189 & -1.439 & .155 & -.339 & .055 \\
\hline impulsive1 & .021 & .118 & .027 & .175 & .862 & -.215 & .256 \\
\hline
\end{tabular}




\begin{tabular}{lrrrrrrr} 
confusion1 & -.053 & .089 & -.079 & -.598 & .552 & -.231 & .125 \\
loyal1 & $\mathbf{. 1 8 1}$ & $\mathbf{. 0 8 6}$ & $\mathbf{. 2 9 6}$ & $\mathbf{2 . 1 0 2}$ & $\mathbf{. 0 3 9}$ & $\mathbf{. 0 0 9}$ & $\mathbf{. 3 5 2}$ \\
\hline
\end{tabular}

Table 4. The regression for amount money in online shopping.

\begin{tabular}{|c|c|c|c|c|c|c|c|}
\hline \multirow[t]{2}{*}{ Model } & \multicolumn{2}{|c|}{$\begin{array}{l}\text { Unstandardized } \\
\text { Coefficients }\end{array}$} & \multirow{2}{*}{$\begin{array}{c}\text { Standardized } \\
\text { Coefficients }\end{array}$} & \multirow[t]{2}{*}{$\mathrm{t}$} & \multirow[t]{2}{*}{ Sig. } & \multicolumn{2}{|c|}{$\begin{array}{l}\text { 95.0\% Confidence Interval for } \\
\text { B }\end{array}$} \\
\hline & B & Std. Error & & & & Lower Bound & Upper Bound \\
\hline (Constant) & .001 & .161 & & .009 & .993 & -.320 & .323 \\
\hline perfect 2 & .051 & .098 & .066 & .526 & .600 & -.143 & .246 \\
\hline brand 2 & .314 & .145 & .384 & 2.171 & .034 & .025 & .603 \\
\hline fashion2 & .428 & .157 & .503 & 2.719 & .008 & .114 & .741 \\
\hline hedonis2 & -.033 & .113 & -.046 & -.293 & .771 & -.260 & .193 \\
\hline value2 & -.174 & .108 & -.241 & -1.621 & .110 & -.389 & .040 \\
\hline impulsive2 & -.033 & .094 & -.040 & -.357 & .722 & -.221 & .154 \\
\hline confusion2 & -.079 & .108 & -.111 & -.726 & .470 & -.295 & .138 \\
\hline loyal2 & .294 & .122 & .484 & 2.421 & .018 & .052 & .537 \\
\hline
\end{tabular}

Table 3 shows the results of regression for frequent in online shopping. It displays that only loyal which influences the frequency for online shopping $(t>1.96)$. It means that Indonesia millennial tends to see their new favourite products. They spent much time to know the latest product by browsing internet .

Table 4 shows the results of regression for the amount money in online shopping. It displays that there are three factors which influence the amount money for online shopping $(t>1.96)$. From the highest score they are fashion, loyal and brand. This findings quite similar with previous research in Korean and USA students [12] and the other study about USA students [11]. Both of studies found that Brand as the highest factor of CDMS in Korean students and the second rank for USA students means that consumers are likely to buy well-known national brands and the latest style and expensive. In fact, this study revealed that habit is similar with Indonesian students as well. Factor habitual/brand loyal orientation that find in the highest rank detected that Indonesian students tend to have brand loyalty. It means that they buy their favourite brand over and over again. Interesting to know that they likely spend the frequency of time to search the products of brand that they like. This result is in line with the Chinese students [13]. The consumers both countries more brand conscious and brand loyal than others. The implication is the company should realize that the brand is very important for consumer millenials. The company should actively advertise their product. It also shows that the consumers millennial do not pay attention to the price of goods for the sake of a product brand. The interesting finding is the loyal variable influences both frequencies and amount money to purchas e the product. It means that the consumer millennial will spend time and money for their favourite products. 


\section{CONCLUSION}

This study shows that only loyal factor from eight CSI factor influences the CDMS. It means that the

consumer millennial in Indonesia spend time and money for their favourite products. The next finding describes that three factors of eight CSI factor influence the amount money dimension of CDMS. They are fashion, loyal and brand. It shows that consumer millennial has the high conscious to the new product or model. This research can be extended by involving various people to compare each CDMS.

\section{REFERENCES}

[1] K. . Chau, Y. Cao, M. Anson, and J. Zhang, "Application of data warehouse and Decision Support System in construction management," Autom. Constr., vol. 12, no. 2, pp. 213-224, Mar. 2003.

[2] L. Ruane and E. Wallace, "Generation Y females online: insights from brand narratives," Qual. Mark. Res. An Int. J., vol. 16, no. 3, pp. 315-335, Jun. 2013.

[3] M. Moore, "Interactive media usage among millennial consumers," J. Consum. Mark., vol. 29, no. 6, pp. 436-444, Sep. 2012.

[4] S. M. Noble, D. L. Haytko, and J. Phillips, "What drives college-age Generation Y consumers?," J. Bus. Res., vol. 62, no. 6, pp. 617-628, Jun. 2009.

[5] G. B. Sprotles and E. L. Kendall, “A Methodology for Profiling Consumers' DecisionMaking Styles,” J. Consum. Aff., vol. 20, no. 2, pp. 267-279, Dec. 1986.

[6] G. P. Moschis and R. L. Moore, "Decision Making Among the Young: A Socialization Perspective,” J. Consum. Res., vol. 6, no. 2, p. 101, Sep. 1979.

[7] N. Y. M. Siu, C. C. L. Wang, L. M. K. Chang, and A. S. Y. Hui, “Adapting consumer style inventory to Chinese consumers: A confirmatory factor analysis approach,” J. Int. Consum. Mark., vol. 13, no. 2, pp. 29-47, 2001.

[8] V.-W. Mitchell and G. Walsh, "Gender differences in German consumer decisionmaking styles,” J. Consum. Behav., vol. 3, no. 4, pp. 331-346, Jun. 2004.

[9] V. S. Nair, D. Gupta, and S. Gunasekar, "Influence of values on quality consciousness among Indian consumers," in 2017 International Conference on Data Management, Analytics and Innovation (ICDMAI), 2017, pp. 177-181.

[10] R. Rana, "High School Students Buying Behavior Towards Fashion Brands of Apparel Products," Thimphu, 2016.

[11] K. O. Cowart and R. E. Goldsmith, "The influence of consumer decision-making styles on online apparel consumption by college students," Int. J. Consum. Stud., vol. 31, no. 6, pp. 639-647, Nov. 2007.

[12] J. L. Hafstrom, J. S. Chae, and Y. S. Chung, "Consumer Decision-Making Styles: Comparison Between United States and Korean Young Consumers," J. Consum. Aff., vol. 26, no. 1, pp. 146-158, Jun. 1992.

[13] J. X. Zhou, M. J. Arnold, A. Pereira, and J. Yu, "Chinese consumer decision-making styles: A comparison between the coastal and inland regions," J. Bus. Res., vol. 63, no. 1, pp. 45-51, Jan. 2010. 